\title{
THE DISTRIBUTION AND MORPHOLOGY OF OPIOID PEPTIDE IMMUNOREACTIVE NEURONS IN THE CEREBRAL CORTEX OF RATS $^{1}$
}

\author{
JACQUELINE F. MCGINTY, ${ }^{2}$ DEREK VAN DER KOOY, ${ }^{3}$ AND FLOYD E. BLOOM \\ Arthur Vining Davis Center for Behavioral Neurobiology, The Salk Institute, San Diego, California 92138
}

Received August 29, 1983; Accepted November 15, 1983

\begin{abstract}
Pharmacological and biochemical evidence has implied that a widespread opioid peptide system exists within the cerebral cortex to mediate a variety of opiate effects. However, immunocytochemical detection of opioid peptides in the cortex has been limited. Using antisera to enkephalin and bovine adrenal medullary peptide, both fragments of proenkephalin, and an antiserum to dynorphin A, a fragment of prodynorphin, we now describe the regional and laminar distribution of a widespread population of olfactory cortical and neocortical cell bodies and fibers with opioid immunoreactivity in rats. Neurons stained with each antiserum are distributed bimodally in layers II and III and V and VI of neocortex as well as in layers II and III of olfactory cortex. The widespread distribution and heterogeneous morphology of cortical cells containing proenkephalin and dynorphin-A immunoreactivity suggest that opioid peptide-containing neurons may influence the functioning of local, commissural, and projection neurons in rat cerebral cortex.
\end{abstract}

Most studies of the immunocytochemical distribution of opioid peptides have suggested that all three opioid families, proopiomelanocortin (Nakanishi et al., 1979), proenkephalin (Gubler et al., 1982; Noda et al., 1982), and prodynorphin (Kakidani et al., 1982), are represented most heavily in subcortical systems (for a review see Bloom and McGinty, 1981; Finley et al., 1981; Weber et al., 1982b; Khachaturian et al., 1983). However, radioimmunoassay (see Miller, 1981 for review) and radioligand binding studies (see Zukin, 1983 for review) consistently detect low to moderate levels of opioid peptides and opiate binding sites, respectively, in the neocortex, paleocortex, and limbic cortex. With the advent

\footnotetext{
${ }^{1}$ We wish to thank R. J. Miller of the University of Chicago, Lars Terenius of Uppsala University, Uppsala, Sweden, and Andrew Baird of The Salk Institute for donating antisera. Special thanks to Nancy Callahan for processing the manuscript, John Morrison for helpful comments and discussion, Kent Slemmons of the Department of Anatomy, East Carolina University School of Medicine for plate preparation, and Rebekah Loy of the University of California, San Diego in whose laboratory J. F. M. concluded this work. This study was supported by Grants DA 01785 and HL 25457 (F. E. B.), NS 14372 (R. L.), and NS 18837 (J. F. M.) from the National Institutes of Health.

${ }^{2}$ To whom correspondence should be directed, at her present address: Department of Anatomy, East Carolina University School of Medicine, Greenville, NC 27834.

${ }^{3}$ Present address: Department of Anatomy, Neurobiology Research Group, University of Toronto, Toronto, Ontario, Canada M5S 1A8.
}

of autoradiography for ligand binding sites, specific laminar and regional distributions of various opioid receptor subtypes have been described in rat (Goodman et al., 1980; Herkenham and Pert, 1982; Lewis et al., 1983), guinea pig (Foote and Maurer, 1982; Goodman and Snyder, 1982), and monkey (Wise and Herkenham, 1982) cortex. This information, coupled with evidence that opiates may influence cerebral cortical information processing (Jaffe and Martin, 1980; Buchsbaum et al., 1982; Arnsten et al., 1983; Reisberg et al., 1983) and electrophysiological events (Satoh et al., 1974, 1976; Nicoll et al., 1977), led us to search more diligently for opioid peptide systems within the cerebral cortex.

Our preliminary observations (McGinty et al., 1982b) described clusters of neurons containing enkephalin and dynorphin-A immunoreactivity (ir) in olfactory and medial cortical (limbic) regions of colchicine-treated rats. Further analysis with antisera raised against the proenkephalin fragment, bovine adrenal medullary peptide (BAM22P) and dynorphin-A in colchicine and kainic acid-treated rats, now has revealed a more heterogeneous population of opioid-containing cortical cells, including bipolar cells, multipolar stellate cells, and presumptive pyramidal cells. Furthermore, enkephalin-ir was detected in fibers within the anterior commissure and corpus callosum. These data suggest that proenkephalin- and prodynorphin-containing cortical neurons may contribute to a variety of local, commissural, associational, and 
long projection pathways, providing a strong cytological basis for the responsiveness of cortical neurons to opiates.

\section{Materials and Methods}

Colchicine (25 to $200 \mu \mathrm{g}$ in 10 to $50 \mu \mathrm{l}$ of saline) was infused into the lateral ventricles of 30 male and female Sprague-Dawley and Fisher 344 rats (200 to $300 \mathrm{gm}$ ) 24 to $48 \mathrm{hr}$ before perfusion. Kainic acid (six rats $-1 \mu \mathrm{g} / \mu \mathrm{l}$ ) was infused into the lateral ventricles of five rats 3 days, 2 weeks, or 2 months before perfusion. Drug-treated and naive rats were perfused with $5 \%$ paraformaldehyde in $0.2 \mathrm{M}$ phosphate buffer and postfixed for 2 to $3 \mathrm{hr}$ as described (McGinty et al., 1983). The brains were stored in $15 \%$ sucrose until they were frozen in dry ice and cut on a sledge microtome. Free-floating sections $(50 \mu \mathrm{m})$ were pre-incubated with $1 \% \mathrm{H}_{2} \mathrm{O}_{2}$ for 5 min to eliminate endogenous peroxidase, rinsed, then incubated with rabbit anti-leucine ${ }^{5}$-enkephalin (A198 or A206 donated by R. J. Miller, University of Chicago) diluted 1:1000, antidynorphin-A (84C donated by Lars Terenius, Uppsala, Sweden) diluted 1:1000, or anti-BAM22P (B6 donated by $A$. Baird, The Salk Institute), diluted 1:2000. The characteristics of each antiserum have been described (Miller et al., 1978; Bloch et al., 1983; McGinty et al., 1983). Control sections were incubated with each antiserum adsorbed for $24 \mathrm{hr}$ at $4^{\circ} \mathrm{C}$ with 1 to $100 \mu \mathrm{M}$ concentration of the peptide against which the antiserum was raised or related opioid peptides (see below). The secondary immunoreagents were either goat-anti-rabbit (GAR) IgG conjugated to horseradish peroxidase (HRP) (conjugated by J. F. M.) diluted 1:1000, GAR IgG-fluorescein isothiocyanate (FITC) (Antibodies, Inc., Davis, CA) diluted 1:50, or GAR IgG-biotin followed by an avidin-biotin-HRP complex (Vectastain, Vector Laboratories, Burlingame, CA). The HRP staining procedure and diluents have been described (McGinty et al., 1983).

In the initial experiments, one $50-\mu \mathrm{m}$ coronal section in $300 \mu \mathrm{m}$ throughout the brain was incubated with antienkephalin. An adjacent series of $50-\mu \mathrm{m}$ sections was stained with cresyl violet. From the latter sections, tracings with relevant cytoarchitectural boundaries were drawn using a Bausch and Lomb microprojector. The distribution of cortical cells containing enkephalin-ir was plotted on these tracings. In later experiments, adjacent serial $50-\mu \mathrm{m}$ sections were incubated with anti-Leu ${ }^{5}-$ enkephalin, anti-dynorphin-A, or anti-BAM22P. The distribution of cells stained with anti-BAM22P was plotted on the maps of enkephalin-ir already compiled.

Photomicrographs were taken with Kodak Technical Pan 2415 film on a Zeiss Universal or a Leitz Orthoplan microscope. The following terminologies were adopted to describe various cortical regions: Haberly and Price (1978a, b) for paleocortex; Krettek and Price (1977a) for frontal cortex; Paxinos and Watson (1982), Swanson et al. (1983), and Zilles et al. (1980) for the remaining areas of neocortex.

\section{Results}

\section{General observations}

All specific staining was eliminated by incubating tissue sections with the antigen against which each anti- serum was raised. Adsorption of the BAM22P antiserum with Met ${ }^{5}$-enkephalin or adsorption of the Leu ${ }^{5}$-enkephalin antisera with BAM22P did not affect specific staining. Adsorption of the Leu-enkephalin antisera with dynorphin-A reduced but did not abolish staining. Dynorphin immunostaining was not affected by adsorption of the dynorphin antiserum with $\mathrm{Leu}^{5}$-enkephalin or BAM22P. In non-colchicine-treated rats, a few cell bodies were weakly stained with each antiserum in olfactory cortical regions, but none were observed in neocortex. Colchicine treatment in the 100 to $200 \mu \mathrm{g}$ range consistently produced the greatest number of immunoreactive cell bodies. Kainic acid-treated rats with survival times ranging from 3 days to 2 months demonstrated less consistent cortical cellular immunoreactivity with each antiserum; however, occasional neurons exhibited extensive somal, axonal, and/or dendritic labeling (see below).

The regional and laminar distribution as well as the morphology of cell bodies containing enkephalin-ir or BAM22P-ir were the same throughout the cerebral cortex of Sprague-Dawley and Fisher 344 rats. While more rigorous experiments are required to document that the cortical cells stained by these antisera are the same, our data and those of others (Khachaturian et al., 1982, 1983) support our tentative reference to them here as one population of proenkephalin-positive cells.

The BAM22P antiserum stained cortical perikarya more intensely than did the enkephalin or dynorphin antisera (Fig. 1). Enkephalin-ir (Fig. $1 A$ ) and dynorphinir (Fig. $1 B$ ) were most prominent in a single proximally bulging process extending from a poorly stained soma. Although many intensely stained, swollen processes could be seen at low magnification (Fig. $1, A$ and $B$ ), few well stained enkephalin- or dynorphin-immunoreactive cell bodies could be seen even at higher magnification (Fig. 1, $A$ and $B$ insets). The basal orientation and bulging of the intensely stained process, especially when observed in the presence of other nonswollen processes emanating from the same soma, suggested that the intensely stained process was the cell's axon, artificially swollen by the colchicine treatment. Such swollen processes were also seen in anti-BAM22P-stained tissue but were more often attached to well stained perikarya (Fig. $1 C$ ). Because the BAM22P antiserum revealed a greater number of strongly immunoreactive neurons in both Sprague-Dawley and Fisher 344 rats than did the dynorphin antiserum, our analysis of the proenkephalin cortical system is more advanced than that of the prodynorphin system.

Because colchicine treatment caused swelling of fibers, more opioid peptide-immunoreactive neuropil was visible in colchicine-treated rats than in normal rats, especially in the deep layers of cortex and in the subcortical white matter. Still, however, the neuropil stained with each antiserum was relatively sparse in the neocortex but more extensive in olfactory (especially entorhinal) cortex. Single fibers in the neocortex were stained with each antiserum and appeared to be largely limited to the individual processes of immunopositive cortical cells. In selected areas of both neocortex and olfactory cortex (see below), axons of cells could be followed from deep layers into the corpus callosum, forceps minor, and anterior commissure. 

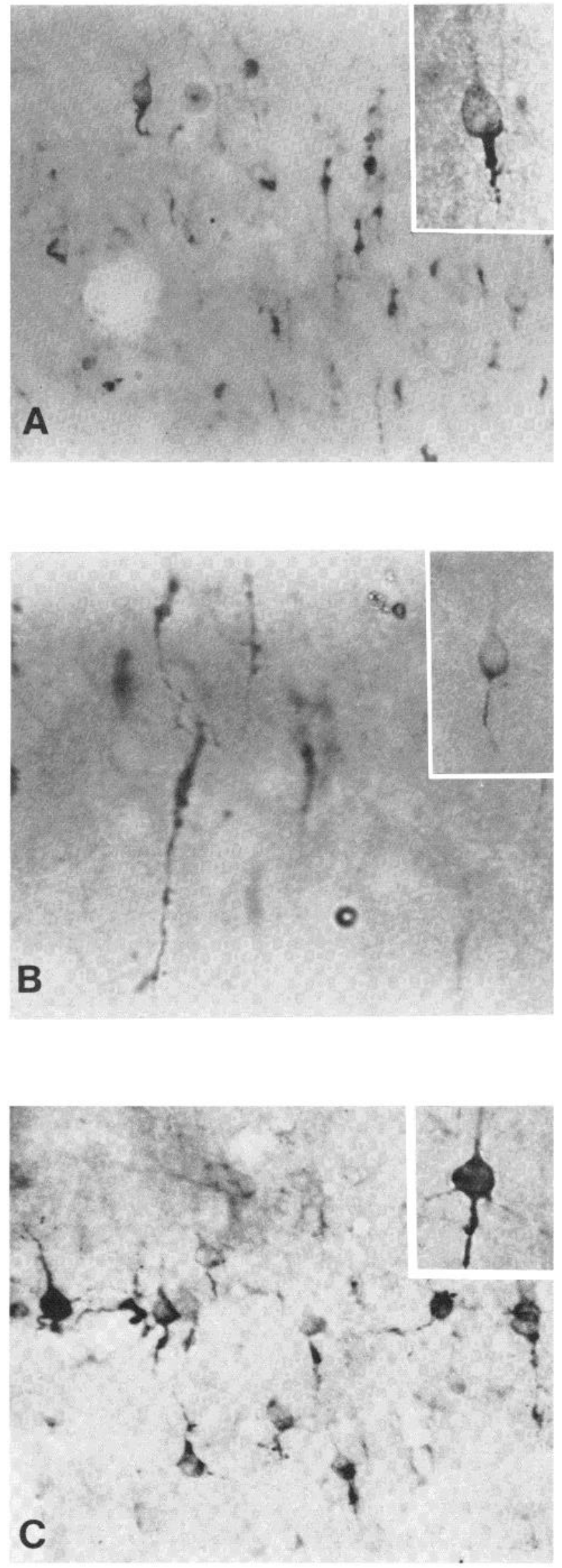

Neurons containing proenkephalin-ir in the olfactory cortex and hippocampus

Distribution. Neuronal perikarya containing proenkephalin-ir were found in all cerebral cortical areas (Fig. 2 ); however, proenkephalin-positive cells were more densely stained and clustered in olfactory cortical than in neocortical areas. Prominent immunostained cells occurred in layers II and III of the entire olfactory cortex. In the olfactory peduncle, cells were found rostrally in the anterior olfactory nucleus, pars lateralis and dorsalis (Fig. 2, $A$ and $B$ ), and caudally in the dorsal peduncular cortex and ventral tenia tecta (Figs. $2 C$ and $3, B$ and $C$ ). Fibers emanating from layer II cells in each of these areas traveled through the deeper polymorphic layers where scattered, polygonal proenkephalin-positive cells were located (Fig. 2, $A$ to $C$ and see below). These fibers appeared to cross into the anterior commissure.

At the level of the striatum (Fig. 2, $D$ and $E$ ), which contains a heavy concentration of proenkephalin-positive cells and fibers (not illustrated, but see Bloch et al., 1983), neurons in the olfactory tubercle and pyriform cortex were well stained. The olfactory tubercle contained many closely packed cells in layer II and scattered cells in layer III (Figs. 2, $D$ and $E$ and $3 E$ ) continuous with those of the striatum. Similarly, throughout the pyriform cortex, loosely packed layer IIA and IIB cells and scattered layer III cells contained proenkephalin-ir (Fig. $3 F$ ). At rostral levels, the most lateral, curved portion of layer II of the pyriform cortex contained many darkly stained cells with axons extending into layer III (Figs. $2 D$ and $3 F$ ). In the mid to posterior portions of pyriform cortex, proenkephalin-positive cells in layer II were less densely packed (Fig. $2, E$ to $H$ ). At this level (Fig. $2 G$ ), the anterolateral cortical amygdaloid nucleus displayed a moderate number of cells, and the posteromedial portion of the cortical amygdaloid nucleus (Fig. $2 \mathrm{H}$ ) contained a dense cluster of cells and fibers.

Caudal to the pyriform cortex (Figs. $2, H$ to $J$ and $3 G$ ), the number of proenkephalin-positive cells increased in the ventrolateral entorhinal cortex (Fig. $3 H$ ) and the perirhinal area. The dense packing of homogeneously shaped cells in layer II of ventrolateral entorhinal cortex was similar to that in other olfactory cortical areas. Polymorphous cells were also scattered in the deeper layers of entorhinal cortex amidst a heavily stained neu-

Figure 1. Intensity and cellular distribution of immunoreactivity differed among cortical neurons stained with different opioid peptide antisera. $A$, Field of colchicine-induced swollen processes and weakly stained perikarya in layers II and III of ventrolateral orbital cortex (VLO). Cortex stained with $\mathrm{Leu}^{5}$ enkephalin antiserum A198 $(\times 396)$. Inset, Detail of enkephalin-immunoreactive neuron in VLO $(\times 660)$. B, Field of dynorphin-immunoreactive swollen processes in layer $\mathrm{V}$ of ventral anterior cingulate $(\mathrm{ACv})$ cortex $(\times 990)$. Inset, Detail of weakly stained dynorphin-immunoreactive neuron in $\mathrm{ACv}(\times 660)$. $C$, Field of BAM22P-immunoreactive neurons in layer $\mathrm{V}$ of somatosensory (SS) cortex ( $\times$ 528). Inset, Detail of BAM22Pimmunoreactive pyramidal cell in SS $(\times 742)$. Note denser perikaryal staining in BAM22P-stained tissue and colchicineinduced swollen basal processes in each case. Colchicine-treated $(100 \mu \mathrm{g})$ Fisher 344 female rats. 


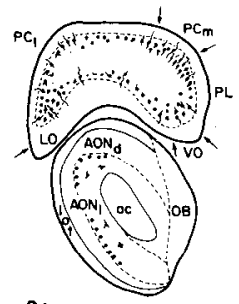

2A

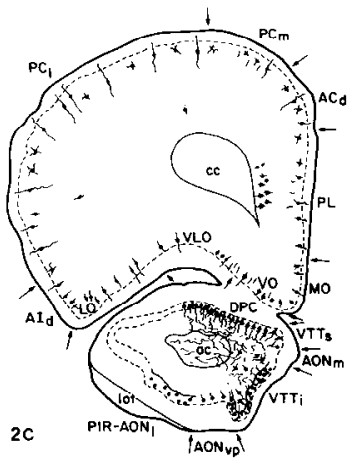

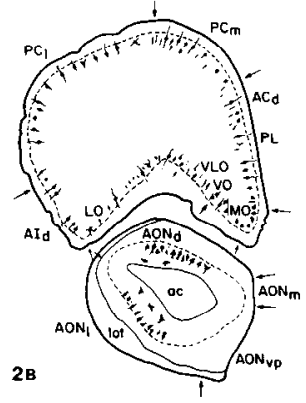
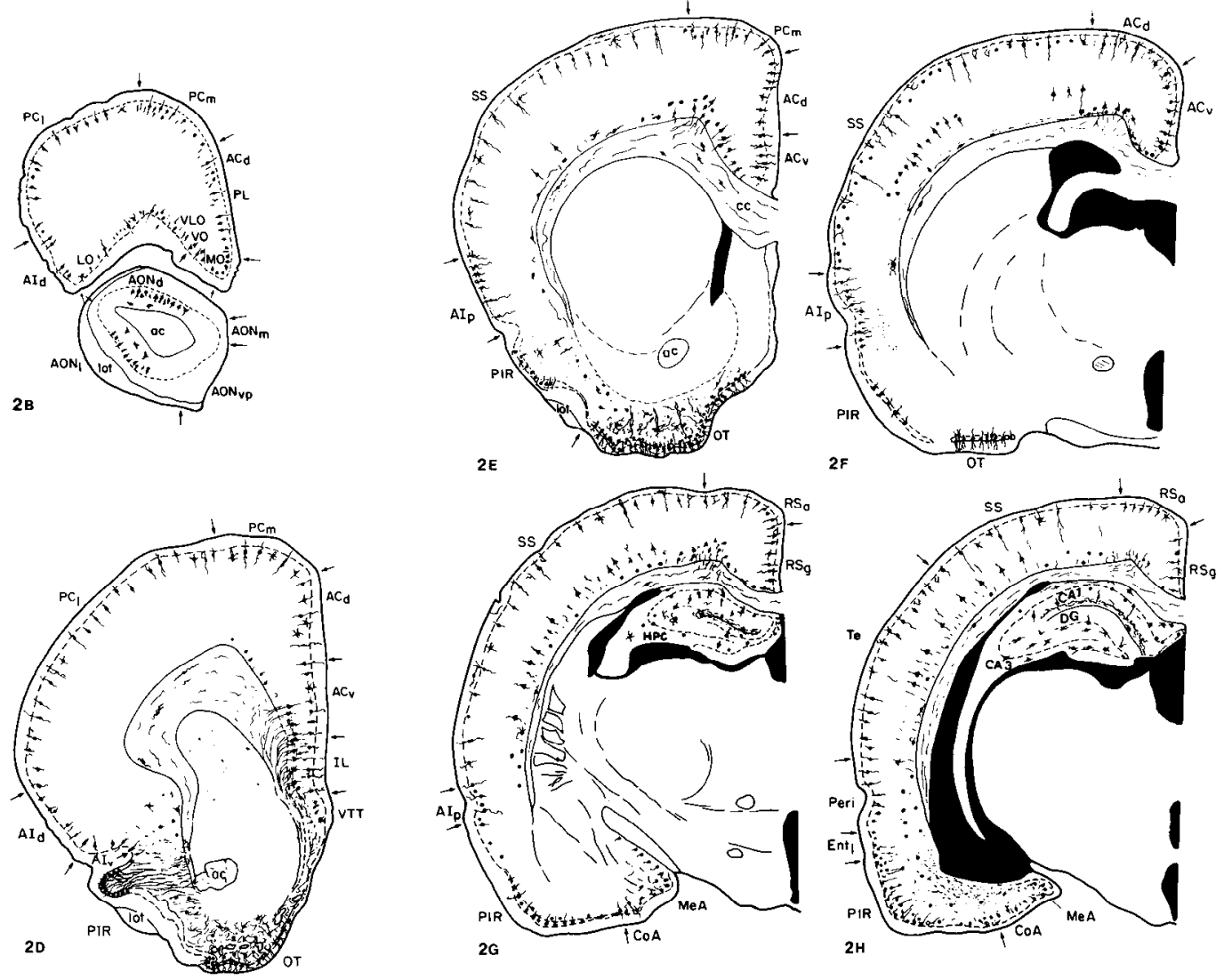

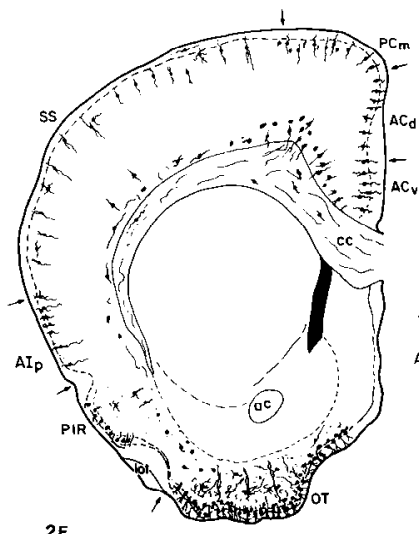

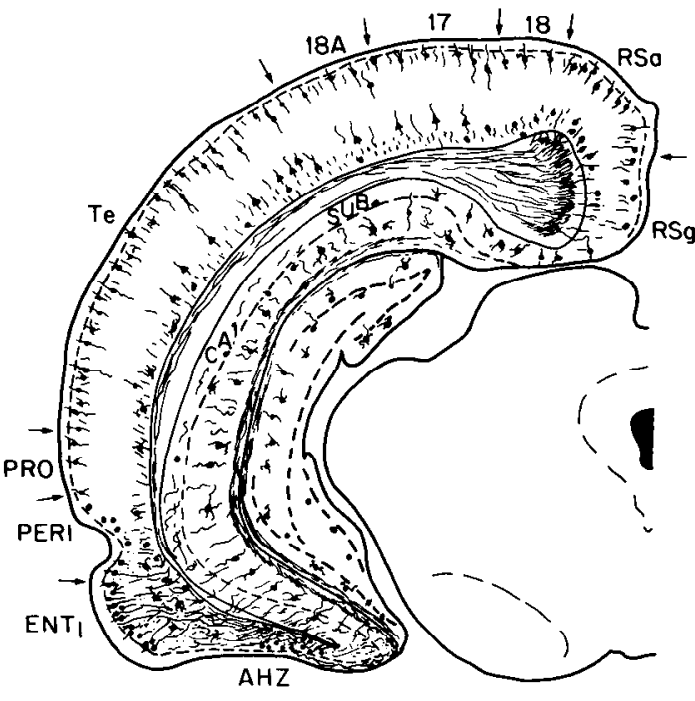

$2 I$

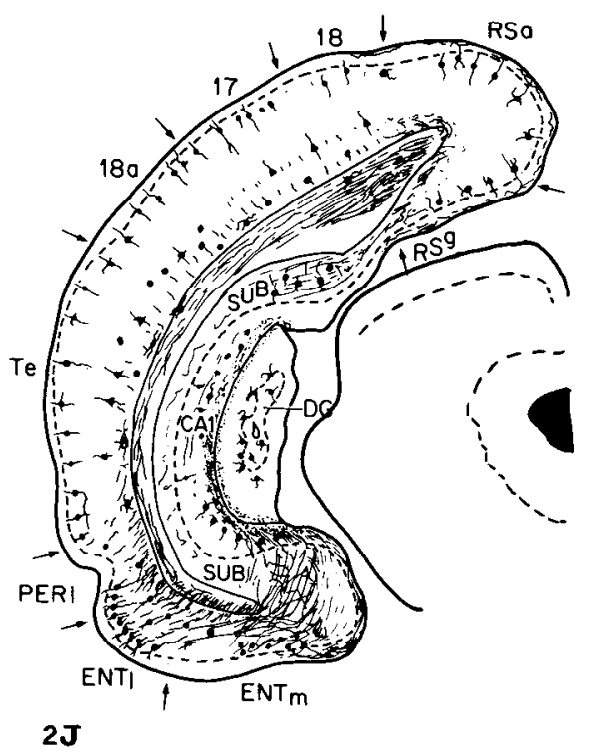

Figure $2 .{ }^{4}$ A series of schematic drawings of rat brain in frontal sections illustrating the distribution of proenkephalinimmunoreactive cell bodies in the cerebral cortex arranged from rostral $(\Lambda)$ to caudal $(J)$.

${ }^{4}$ The abbreviations used in Figure 2 are: $A C_{d, v}$, anterior cingulate cortex (dorsal, ventral); $A H Z$, amygdalo-hippocampal zone; $A l_{d, p, v}$, agranular insular cortex (dorsal, posterior, ventral); $A O N_{d, l, v p}$, anterior olfactory nucleus (dorsal, lateral, ventroposterior); $C A$, cornu ammonis field (hippocampus); $C o A$, cortical nucleus of amygdala; $D G$, dentate gyrus; $E N T_{l, m}$, entorhinal cortex (lateral, medial); $H P C$, hippocampus; $I L$, infralimbic cortex; $L O$, lateral orbital cortex; $M e A$, medial nucleus of amygdala; $M O$, medial orbital cortex; $O B$, olfactory bulb; $O T$, olfac- tory tubercle; $P C_{l, m}$, precentral motor cortex (lateral, medial); $P E R I$, perirhinal cortex; $P I R$, piriform cortex; $P L$, prelimbic cortex; $P R O$, prorhinal cortex; $R S_{a, k}$, retrosplenial cortex (agranular, granular); $S S$, somatosensory cortex; $S U B$, subiculum; Te, temporal cortex; VLO, ventral lateral orbital cortex; $V O$, ventral orbital cortex; $V T T_{i, s}$, ventral tenia tecta (inferior, superior); ac, anterior commissure; $c c$, corpus callosum; lot, lateral olfactory tract; $17,18,18 a$, occipital cortical areas. 
ropil (see below). The layer II cells containing proenkephalin-ir in ventrolateral entorhinal cortex extended from the rhinal sulcus to the medial entorhinal cortex border (Fig. 2, $I$ and $J$ ). The axons of these cells were visible for several millimeters within a section cut either in the coronal or horizontal planes. These fibers extended toward the ventral hippocampus in a loose bundle as part of the perforant path coursing transversely through the deep layers of the lateral entorhinal cortex. At the medial entorhinal cortex border, the fibers either turned dorsally and rostrally to join the tapetum of the corpus callosum or continued longitudinally through deep layers of medial entorhinal cortex (Fig. 2, $I$ and $J$ ) across the subiculum. These fibers presumably formed the enkephalin-positive terminal field in the outer one-third of the molecular layer of ventral caudal Ammon's horn and fascia dentata as described (Gall et al., 1981). Whereas the BAM22P antiserum stained the entorhinal cell bodies from which the perforant path originates better than did the enkephalin antiserum, the opposite was true of the intrahippocampal fiber and terminal staining. Within the dorsal, and especially the ventral, subiculum and hippocampus, proenkephalin-positive, dynorphinnegative cells were found in a similar distribution (see Fig. 2, $G$ to $J$ ) to that which has been described with anti-enkephalin sera (Gall et al., 1981). BAM-ir in these polymorphous hippocampal cells was more pronounced than enkephalin-ir. Figure $3 I$ illustrates nonpyramidal BAM22P-immunoreactive neurons in the CA3 field of the hippocampus of a Fisher rat. In addition, however, BAM22P-immunoreactive mossy fibers are present in the Fisher rat (Fig. 3I). This is in contrast to a lack of BAM22P immunostaining in mossy fibers of SpragueDawley rats used in this and our previous (McGinty et al., 1983) studies.

Neuronal morphology. In each area of the olfactory cortex, proenkephalin-immunoreactive cells in layer II (Fig. $4, A$ to $C$ ) gave rise to a variable number of basal dendrites and a prominent apical dendritic tree. Figure $4 B$ illustrates unusually well stained cells with spiny apical dendrites (Fig. $4 B$, inset) extending into layer I of the olfactory tubercle in a kainic acid-pretreated rat. The axons of these and other proenkephalin-positive cells in olfactory cortex arose from the base of the somata and extended into the polymorphic layer. In some cases, the axons projected into the subcortical white matter. The location, shapes, and axon orientation of the proenkephalin-positive layer II cells in the olfactory cortex suggested that they were pyramidal-type neurons of the sort stained in Golgi preparations (Price, 1973; Haberly and Price, 1978a, b; Heimer and Kalil, 1978).
Scattered multipolar cells in the polymorphic layers of the olfactory cortex were darkly stained with BAM22P antiserum. Although heterogeneous in morphology and orientation, similar cell types appeared in each olfactory cortical area from the anterior olfactory nucleus (Fig. $4 D$ ) through the entorhinal cortex (Fig. $4 E$ ). All layers of the hippocampal formation also contained many BAM22P-immunoreactive cell types (Figs. $3 I$ and $4 F$ ). Figure $4 G$ illustrates a pyramidal basket cell in the granule cell layer of the dentate gyrus of a SpragueDawley rat.

\section{Neurons containing proenkephalin-ir in neocortex}

Neuronal distribution. Polymorphous proenkephalinA-positive cells were scattered throughout the neocortex in layers II and III and V and VI. At the tip of the frontal pole (Fig. 2A), many small proenkephalin-positive cells were present throughout layers II and III of medial and lateral cortex. Further caudal (Fig. 2, $B$ and $C$ ) medial, ventral, and ventrolateral orbital areas appeared to contain the greatest density of stained cells. At the level of the rostral striatum (Fig. $2 D$ ), in addition to layers II and III cells, many closely packed, medium-sized, pyramidal-like cells containing proenkephalin-ir appeared in layers V and VI of prelimbic and infralimbic cortex among a moderately stained neuropil (Fig. 5A). Fibers from these cells in layers $\mathrm{V}$ and VI extended into the forceps minor of the corpus callosum (Figs. $2 D$ and $5 B$ ). A few scattered cell bodies also lay in the white matter of the corpus callosum itself.

At the level of the septal nuclei (Fig. $2 E$ ), the distribution of proenkephalin-positive cells in layers II and III was most prominent in the anterior cingulate, medial precentral, and agranular insular cortex. At this and more caudal levels (Fig. 2, $E$ to $J$ ) proenkephalin-positive cells in layers II and III (Fig. $5 \mathrm{C}$ ) and $\mathrm{V}$ and VI were scattered throughout the neocortex. Axons of layers $\mathrm{V}$ and VI cells, particularly notable in the cingulate cortex, were followed into the corpus callosum, contributing to the population of proenkephalin-positive fibers traveling in the subcortical white matter.

At the level of the retrosplenial cortex (Fig. 2, $G$ to $J$ ), stained pyramidal cells in the lateral neocortex increased in number in layer $\mathrm{V}$ of somatosensory (Fig. 2, $G$ and $H$ ) and especially auditory (temporal) areas (Fig. 2, $\mathrm{H}$ and $I$ ). In occipital cortex (Fig. 2, $I$ and $J$ ), the number of proenkephalin-positive cells appeared to decrease relative to other sensory neocortical areas, especially in layer V. The retrosplenial cortex generally did not contain as many stained cells in any layer as did the cingulate cortex.

Figure 3. Laminar distribution of proenkephalin-immunoreactive neurons in the olfactory cortex. $A$, Schematic drawing with boxed areas indicating the location of stained neurons illustrated in $B$ and $C$. $B$, Neurons stained with Leu ${ }^{5}$-enkephalin antiserum A198 in layer II of the dorsal peduncular cortex of a male Sprague-Dawley rat $(\times 273)$. $C$, Neurons stained with Leu ${ }^{5}$-enkephalin antiserum A198 in layers II and III of inferior ventral tenia tecta (VTTi) of a female Fisher 344 rat ( $\times$ 164). Inset, Detail of $\mathrm{Leu}^{5}$-enkephalin-immunoreactive cell from VTTi $(\times 660)$. $D$, Schematic drawing with boxed areas indicating locations of stained neurons in $E$ and $F . E$, Swollen processes stained with Leu ${ }^{5}$-enkephalin antiserum A198 in layers II and III of olfactory tubercle of male Sprague-Dawley rat $(\times 112)$. Inset, BAM22P-immunostained cell bodies in layer II of olfactory tubercle of male SpragueDawley rat $(\times 413) . F$, BAM22P-immunostained neurons in layers II and III of pyriform cortex $(\times 164)$. G, Schematic drawing with boxed areas indicating locations of stained neurons in $H$ and $I$. $H$, BAM22P-immunostained neurons in layer II of ventrolateral entorhinal cortex of a Fisher 344 rat $(\times 396)$. I, BAM22P-immunoreactive neurons in the CA3 field of the hippocampus. Cells in stratum oriens and stratum pyramidale surround BAM22P-immunoreactive mossy fibers in a colchicinetreated $(100-\mu \mathrm{g})$ female Fisher 344 rat $(\times 75)$. 

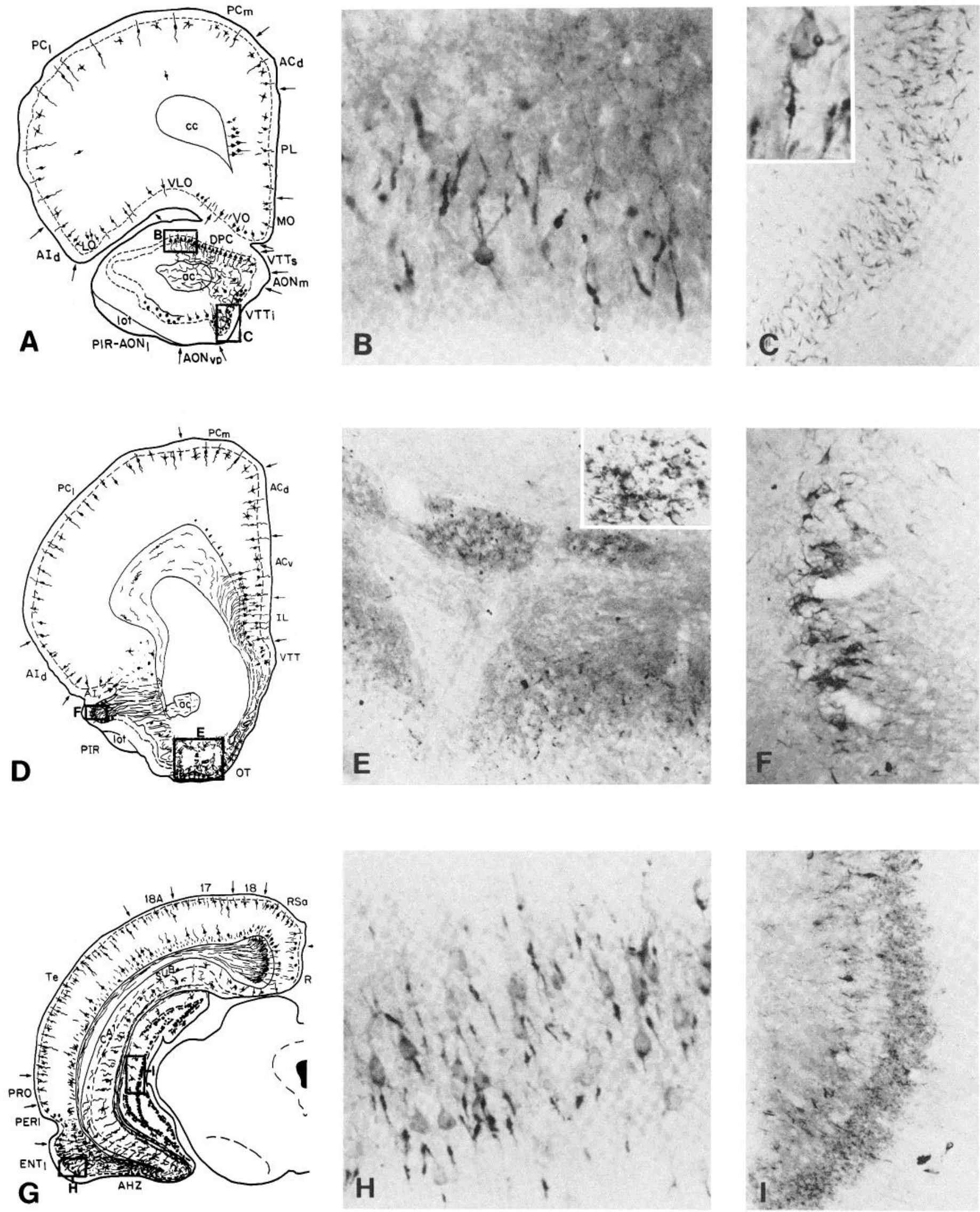

Figure 3 

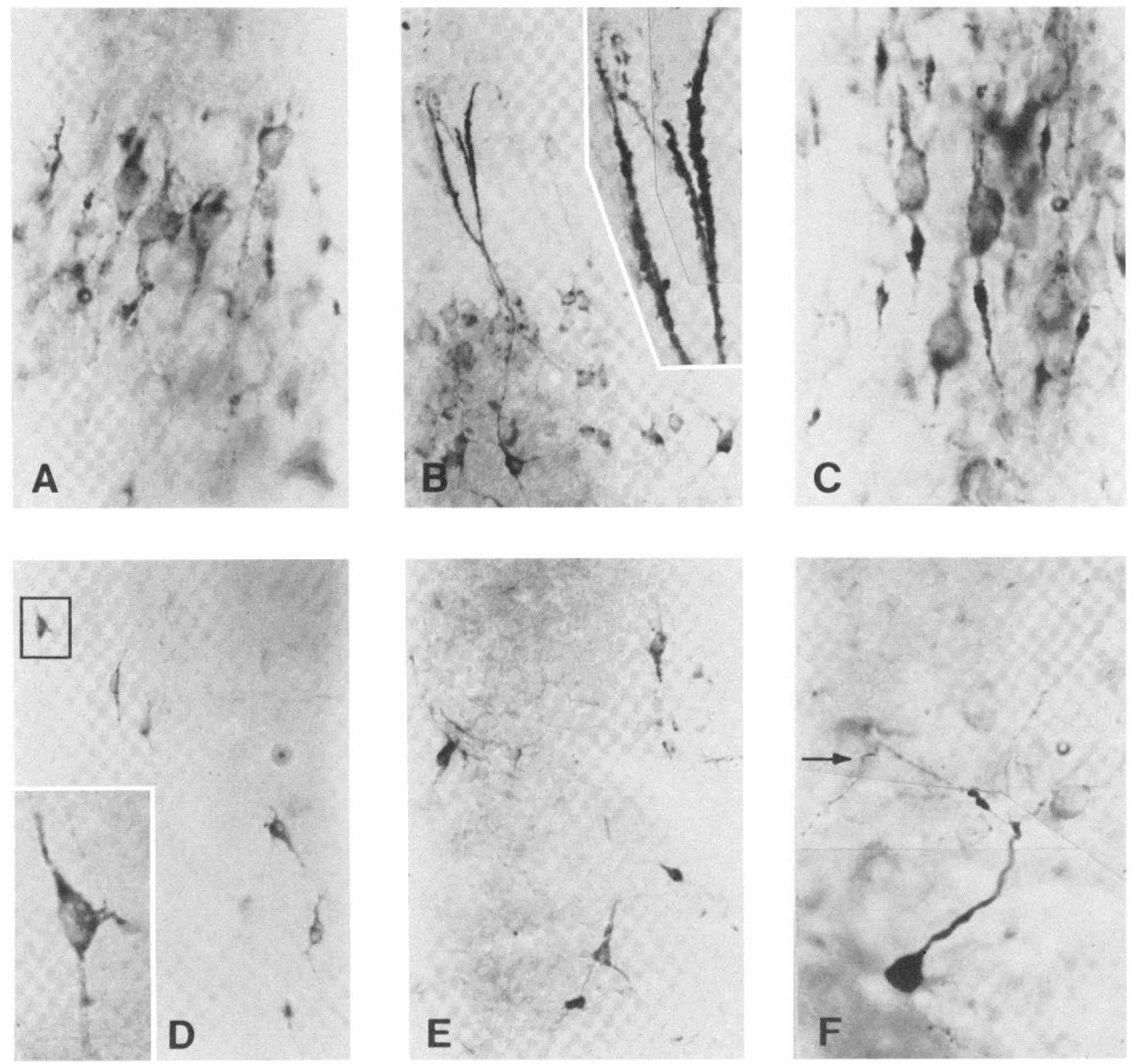

Figure 4. Morphology of proenkephalin-immunoreactive cell types in the olfactory cortex and hippocampus. $A$, Leu ${ }^{5}$ enkephalin-immunoreactive pyramidal cells in layer II of the dorsal peduncular cortex of a colchicine-treated (50 $\mu \mathrm{g}$ in $50 \mu \mathrm{l}$ of saline) male Sprague-D xwley rat $(\times 770)$. B, BAM22P-immunoreactive pyramidal cells in layers IIa and IIb of the olfactory tubercle of a female Fisher 344 rat infused with a single dose of kainic acid (1 $\mu \mathrm{g}$ in $1 \mu \mathrm{l}$ of PBS) 1 month before perfusion $(\times$ $302)$. Inset, Detail of layer I spiny dendrites in $B(\times 770)$. $C$, BAM22P-immunoreactive pyramidal cells in layer II of perirhinal cortex of a colchicine-treated female Fisher 344 rat. Note prominent colchicine-induced axonal swellings $(\times 205) . D$, BAM22Pimmunoreactive cells in the polymorphic layer of the anterior olfactory nucleus $(\times 302)$. Inset, Detail of cell boxed in $D(\times 924)$. $E$, BAM22P-immunoreactive cells in the polymorphic layer of the lateral entorhinal cortex. Note similar morphologies of cells to those in $D(\times 317) . F$, Montage of a BAM22P-immunoreactive pyramidal basket cell in the granule cell layer of the dentate gyrus. Arrow, axon arising from apical dendrite to innervate granule cells $(\times 760)$.

Morphology. Proenkephalin-immunoreactive cells in layers II and III in all neocortical regions generally were either multipolar with irregularly shaped (Fig. 6A) or round (Fig. $6 B$ ) somata, or bipolar with vertically elongated somata (Fig. $6 C$ ). Bipolar cells had a primary apical dendrite extending into layer I and a basal dendrite extending into deep layers for an unknown distance. Both the apical and basal dendritic extensions of bipolar cells were narrowly restricted in the vertical plane. The basal dendrite often branched, giving rise to a swollen process (presumably the axon) and a nonswollen process (presumably the dendritic continuation). BAM/enkephalin-positive cells in layers $\mathrm{V}$ and $\mathrm{VI}$ also were polymorphous. A few bipolar cells (Fig. $6 D$ ) and a greater number of medium to large multipolar cells (Fig. $6 E$ ) were stained in layer V. Medium and large BAM/enkephalin-immunostained layer $\mathrm{V}$ cells were observed with one prominent apical dendrite, several basal dendrites, and often a swol- 


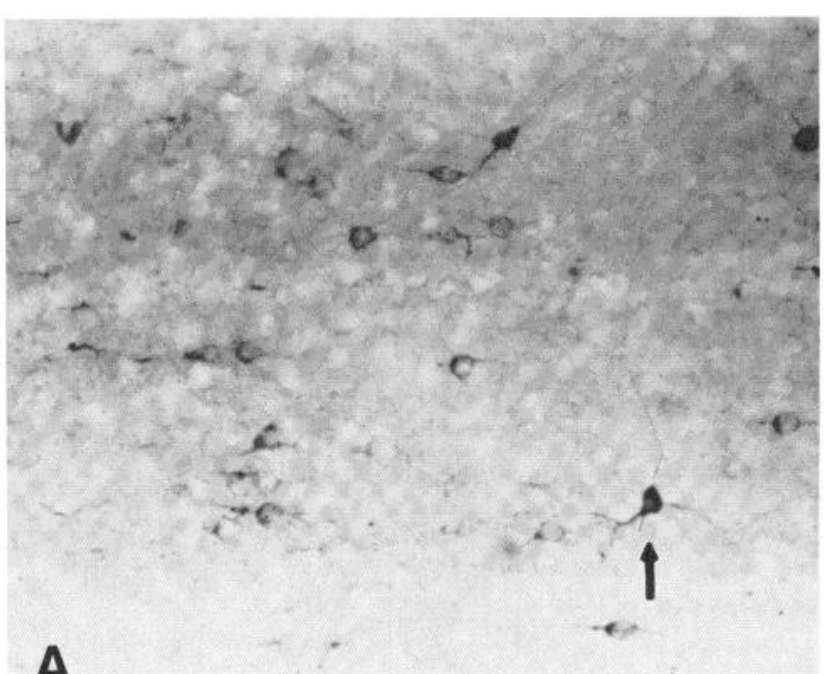

A
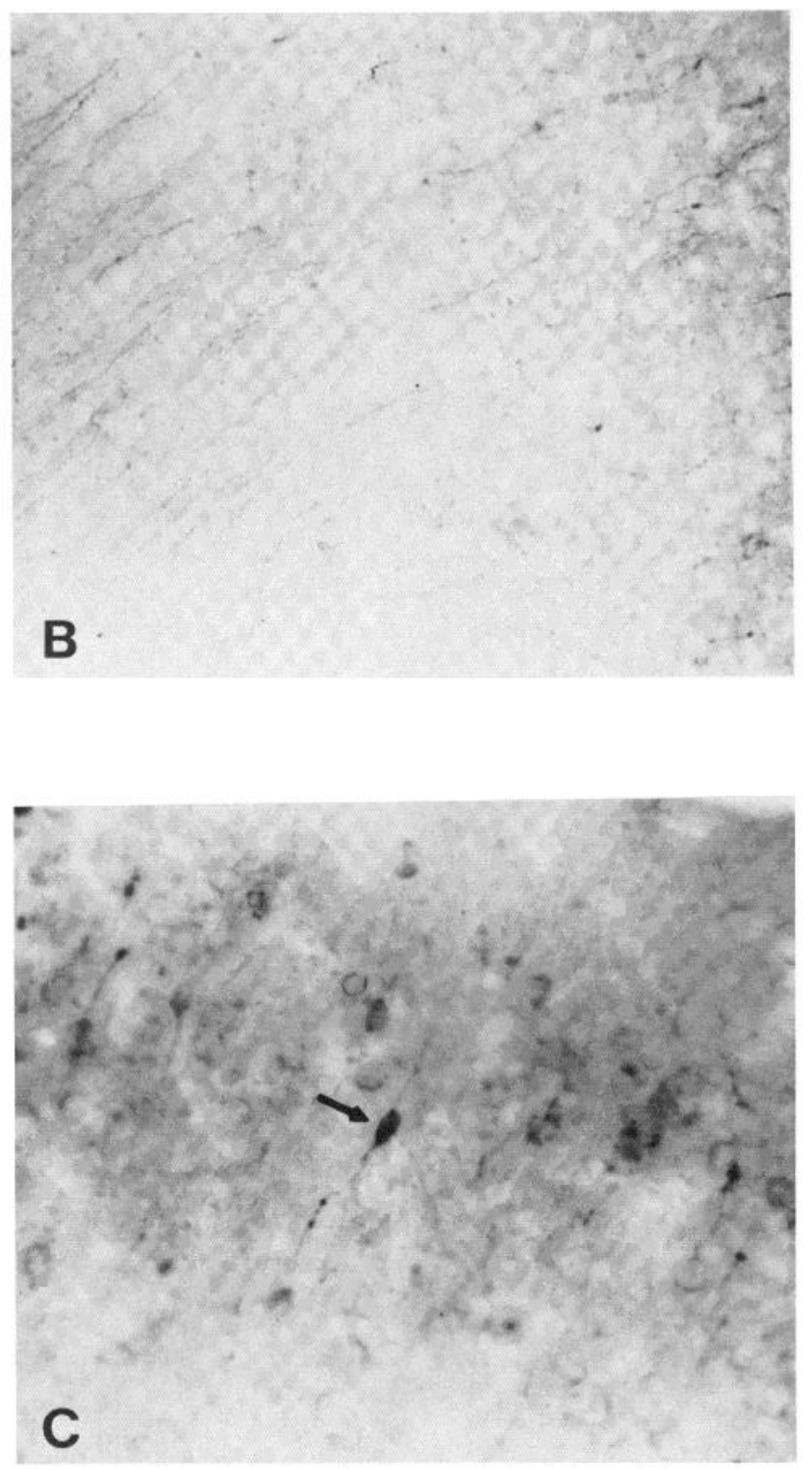

len process emanating from the center of the basal border of the cell (Fig. 6, $F$ to $H$; also see Fig. 1). These cell bodies closely resembled layer V pyramidal cells in Golgi preparations (Ramón y Cajal, 1911). Isolated horizontal cells containing proenkephalin-ir were occasionally observed in layer I, but were more frequently observed in layer VI (Fig. 6I), and were also present in the superficial white matter of the corpus callosum.

\section{Cortical cells containing dynorphin-A-ir}

The intensity of dynorphin-A-ir in most cortical perikarya was far below that obtained with either the enkephalin or BAM22P antisera (see Fig. 1). Furthermore, the dynorphin-A antiserum stained fewer cells in the cerebral cortex of Sprague-Dawley rats than in the cortex of Fisher 344 rats. In both strains, however, dynorphinir was visualized only in areas of the olfactory and neocortex which also contained proenkephalin-ir (Fig. 6). In Sprague-Dawley rats, a few dynorphin-A-immunoreactive swollen processes and weakly stained perikarya were observed in orbital (ventral and medial orbital cortex) and infralimbic cortex, parts of olfactory cortex (dorsal peduncular cortex and olfactory tubercle), and a few layer $\mathrm{V}$ pyramidal cells in neocortex. The distribution of dynorphin-A-ir in hippocampal granule cells and mossy fibers of Sprague-Dawley rats has been described (McGinty et al., 1983).

In Fisher 344 rats, dynorphin-ir was prominent in layer II of the dorsal peduncular cortex (Fig. $7 A$ ), ventral tenia tecta (Fig. $7 B$ ), medial and ventral orbital cortex, and in layers $\mathrm{V}$ and VI of the infralimbic (Fig. $7 C$ ) and prelimbic cortices. Further caudal, layers V and VI of cingulate cortex (see Fig. $1 B$ ) demonstrated dynorphin-ir. In the olfactory tubercle, there was a prominent field of swollen processes containing dynorphin-ir (Fig. $7 D$ ) which dipped into the tubercle crenulations and surrounded the unstained islands of Calleja as in proenkephalin-positive tissue (see Fig. $3 E$ ). In somatosensory and temporal neocortex, layer $\mathrm{V}$ pyramidal cells were visualized (Fig. $7 E$ ), although more weakly stained and fewer in number than those containing proenkephalin-ir in adjacent sections. A few lightly stained cells were present in layer II of the lateral (Fig. $7 F$ ) and medial entorhinal cortex. The few dynorphin-ir fibers in entorhinal cortex did not appear to contribute significantly to innervation of the hippocampal formation via the perforant pathway.

\section{Discussion}

Radioimmunoassays have indicated the existence of proenkephalin-derived peptides like $\mathrm{Met}^{5}$ - and $\mathrm{Leu}^{5}$-enkephalin (Hughes et al., 1977; Simantov et al., 1977;

Figure 5. Laminar distribution of proenkephalin-immunoreactive cells in neocortex. $A$, Leu ${ }^{5}$-enkephalin-immunoreactive pyramidal and nonpyramidal (arrow) cells in layers $\mathrm{V}$ and VI of infralimbic cortex $(\times 260)$. $B$, Leu ${ }^{5}$-enkephalin-immunoreactive fibers in layer VI on the edge of forceps minor of corpus callosum in infralimbic cortex $(\times 200)$. C, BAM22P-immunoreactive cells in layers II and III of somatosensory cortex. The arrow points to a prominent bipolar cell $(\times 200)$. Colchicinetreated $(100-\mu \mathrm{g})$ female Fisher 344 rats. 
Yang et al., 1977; Gros et al., 1978; Miller et al., 1978) and BAM22P (Hollt et al., 1982), as well as prodynorphin-derived peptides like dynorphin-A(1-13) (Goldstein and Ghazarossian, 1980), dynorphin-A (1-8) (Hollt et al., 1980; Weber et al., 1982a), and $\alpha$-neo-endorphin (Minamino et al., 1981; Weber et al., 1982b) in large, poorly defined cortical areas. Although there is evidence for variable processing of proenkephalin in different tissues (Lewis et al., 1978; Hollt et al., 1982; Liston et al., 1983) and of prodynorphin in different brain regions (Weber et al., 1982a), the major forms of proenkephalin and prodynorphin in specific cortical regions are as yet unknown.

The data presented here provide immunocytochemical evidence for a widespread population of polymorphous neurons which contain proenkephalin and/or prodynorphin immunoreactivity in the cerebral cortex of colchicine-treated rats. These neurons were observed in dense clusters in layers II and III and in scattered patches in deeper layers of olfactory (including entorhinal) cortex. In the neocortex and in periallocortical-proisocortical transitional areas (orbitofrontal, agranular insular, infralimbic, and prelimbic cortex; see Reep and Winans, 1982), layers II and III and V and VI contain loosely packed immunostained neurons which correspond to bipolar and multipolar stellate cells and typical pyramidal cells. Regional differences were observed in the abundance of immunostained cells. Compared to neocortex, olfactory cortex contained more neurons which were densely clustered and intensely stained with each antiserum and transitional cortical areas contained an intermediate proportion of cells.

In non-colchicine- or non-kainic acid-pretreated rats, few cortical perikarya or processes displayed immunoreactivity when incubated with the antisera employed in this study. After colchicine pretreatment, the BAM22P antiserum stained intracortical neurons more completely and intensely than did the Leu ${ }^{5}$-enkephalin or dynorphin antisera. In general, cortical perikarya demonstrated weaker dynorphin-A-ir or enkephalin-ir than did subcortical cells stained with the same antisera (see McGinty et al., 1982a, 1983). These differences in antisera staining abilities could reflect (1) differences in the effects of colchicine action or fixation on cortical and subcortical neurons, or (2) variability in the quantity of peptide synthesized per cell population, or (3) differences in the post-transcriptional processing of proenkephalin and prodynorphin in cortical and subcortical regions. None of these or other possibilities have been investigated yet.

The similar cortical distribution of BAM22P-ir and enkephalin-ir is consistent with the concept that both antisera stain the same population of neurons in the
CNS (Khachaturian et al., 1982b, 1983; Bloch et al., 1983). However, dynorphin-A-ir was observed in a similar, albeit less abundant, population of cortical cells as that containing BAM/enkephalin-ir. The overlap was particularly striking in the hippocampal and cortical areas of Fisher 344 rats where the dynorphin immunostaining was robust. Attempts to understand the strain differences in cortical opioid peptide staining and whether proenkephalin and prodynorphin-derived peptides coexist in cortical cells and dentate granule cells will require further analysis.

Prior to the present study, reports of cortical proenkephalin-ir neurons have been limited. Cortical dynorphin-ir has been localized in isolated scattered cells (McGinty et al., 1982a; Vincent et al., 1982) and isolated fiber segments in neocortex (Khachaturian et al., 1982a; McGinty et al., 1982a; Vincent et al., 1982; Weber et al., 1982b). While the present manuscript was being completed, an immunocytochemical description of BAM/ enkephalin-ir in rat telencephalon was published (Khachaturian et al., 1983). In that study, immunopositive cells were found primarily in olfactory, cingulate, and retrohippocampal cortex with few, scattered cells in the neocortex of rats treated with high doses of colchicine. The latter authors reported a more extensive distribution of proenkephalin-immunoreactive neurons in corlex than had previous studies (Sar et al., 1978; Wamsley et al., 1980; Finley et al., 1981; Gall et al., 1981; Khachaturian et al., 1982b). However, Khachaturian and colleagues did not report the presence of proenkephalinpositive cells throughout neocortex nor did they note the heterogeneity of stained cell types that was described and illustrated in the present study.

Prominent colchicine-induced swollen processes of enkephalin-immunoreactive cortical neurons have been observed previously (Gall et al., 1981; Khachaturian et al., 1982b, 1983; McGinty et al., 1982b, 1983). Gall and colleagues (1981) noted the "pathological-looking swelling" of "brilliantly immunoreactive proximal axons" attached to more faintly stained entorhinal cortical perikarya after colchicine treatment. As we have noted here, the intense immunostaining of swollen proximal axons in colchicine-pretreated tissue was our first clue (McGinty et al., 1982b) to the presence of a widespread population of opioid peptidergic cells in the cortex. Although colchicine is believed to affect cellular staining by blocking axoplasmic transport, it has other deleterious effects (Hindelang-Gertner, 1976). Nevertheless, its use has enabled a first approximation of opioid peptidergic cell types in cortex with putative axons distinguishable from dendrites in optimal cases.

The use of kainic acid to visualize immunoreactive perikarya and their processes in this study developed

Figure 6. Morphology of proenkephalin-immunoreactive cell types in the neocortex. A, BAM22P-immunoreactive multipolar cell with irregularly shaped soma in layer II of somatosensory cortex $(\times 990)$. B, BAM22P-immunoreactive multipolar cell with round soma in layer II of temporal cortex $(\times 740)$. $C$, BAM22P-immunoreactive bipolar cell in layer II of somatosensory cortex $(\times 880), D, B A M 22 \mathrm{P}$-immunoreactive bipolar cell in layer $\mathrm{V}$ of medial precentral cortex. Note colchicine-induced swollen basal process (presumptive axon) arising from dendrite in $E$ and $F$ (arrows) $(\times 825) . E$, BAM22P-immunoreactive multipolar cell in layer $\mathrm{V}$ of medial precentral cortex $(\times 1240)$. F, BAM22P-immunoreactive pyramidal cells in layer $\mathrm{V}$ of posterior agranular insular cortex $(\times 1050)$. $G$, Enkephalin-immunoreactive pyramidal cell in layer $\mathrm{V}$ of somatosensory cortex $(\times 990)$. $H$, BAM $22 \mathrm{P}$ immunoreactive pyramidal cells in layer $\mathrm{V}$ of somatosensory cortex $(\times 825)$. $I$, BAM22P-immunoreactive horizontal cell in layer VI of posterior agranular insular cortex $(\times 920)$. Colchicine-treated $(100-\mu \mathrm{g})$ female Fisher 344 rats. 


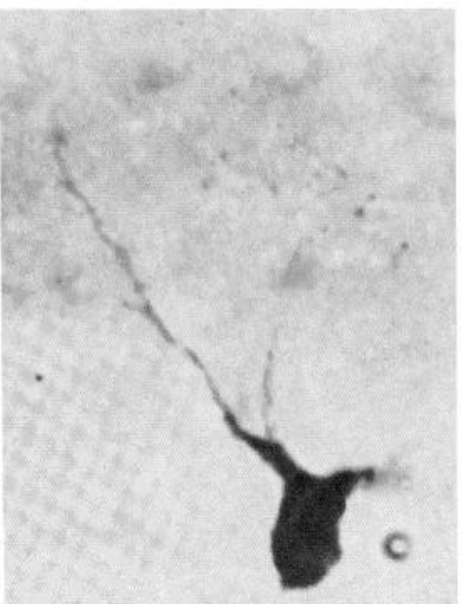

A
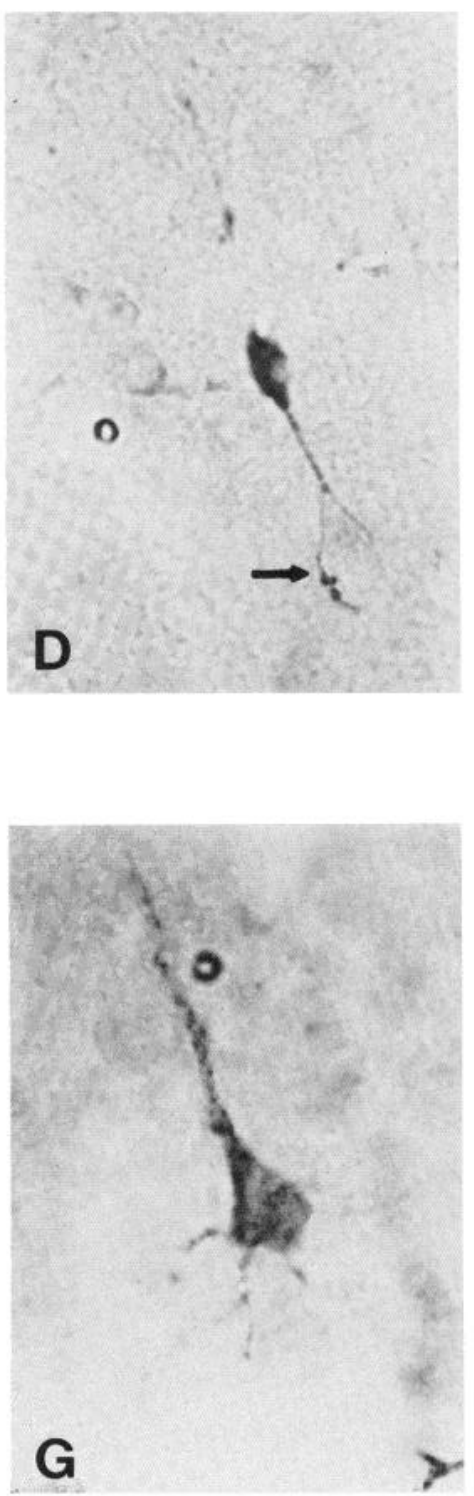
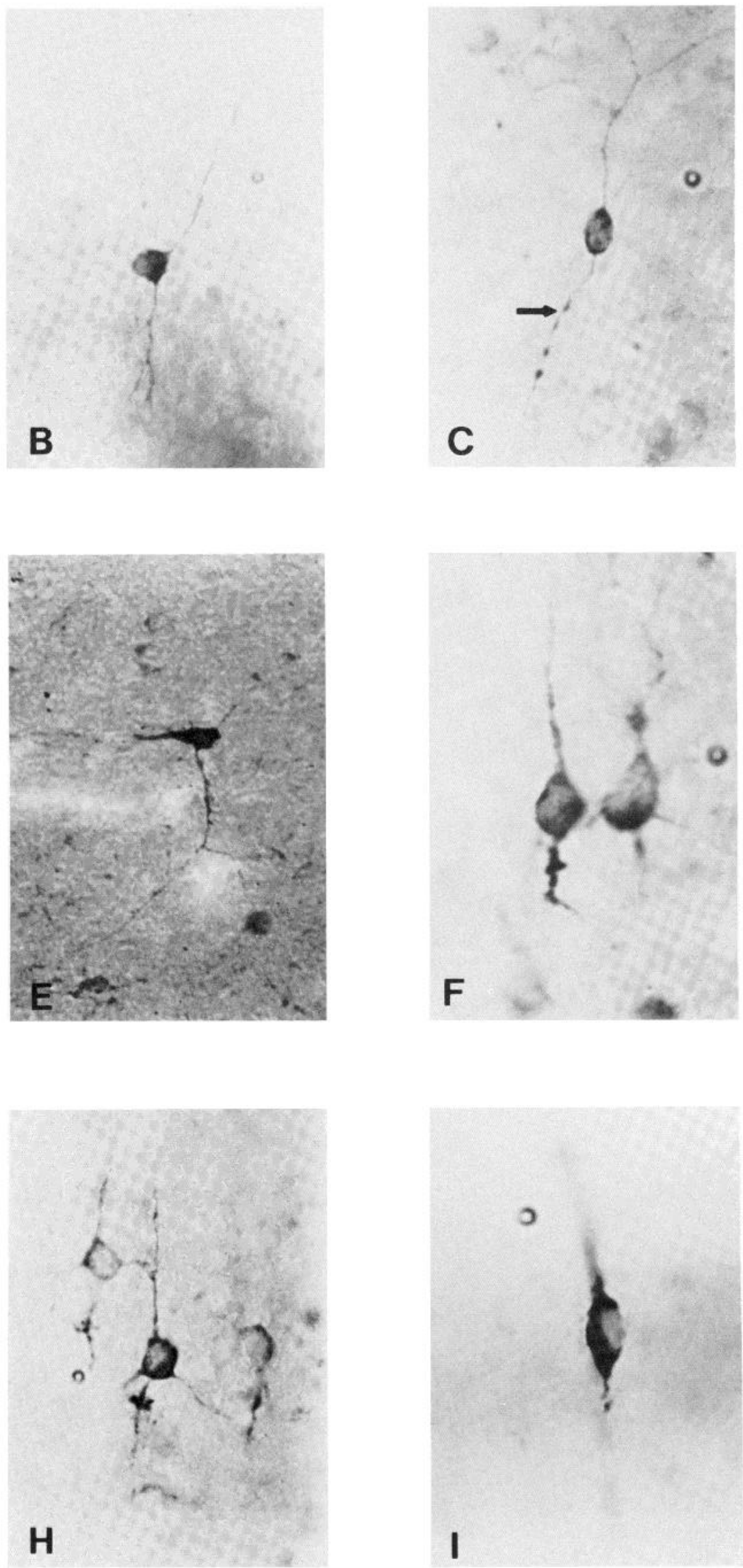

Figure 6 

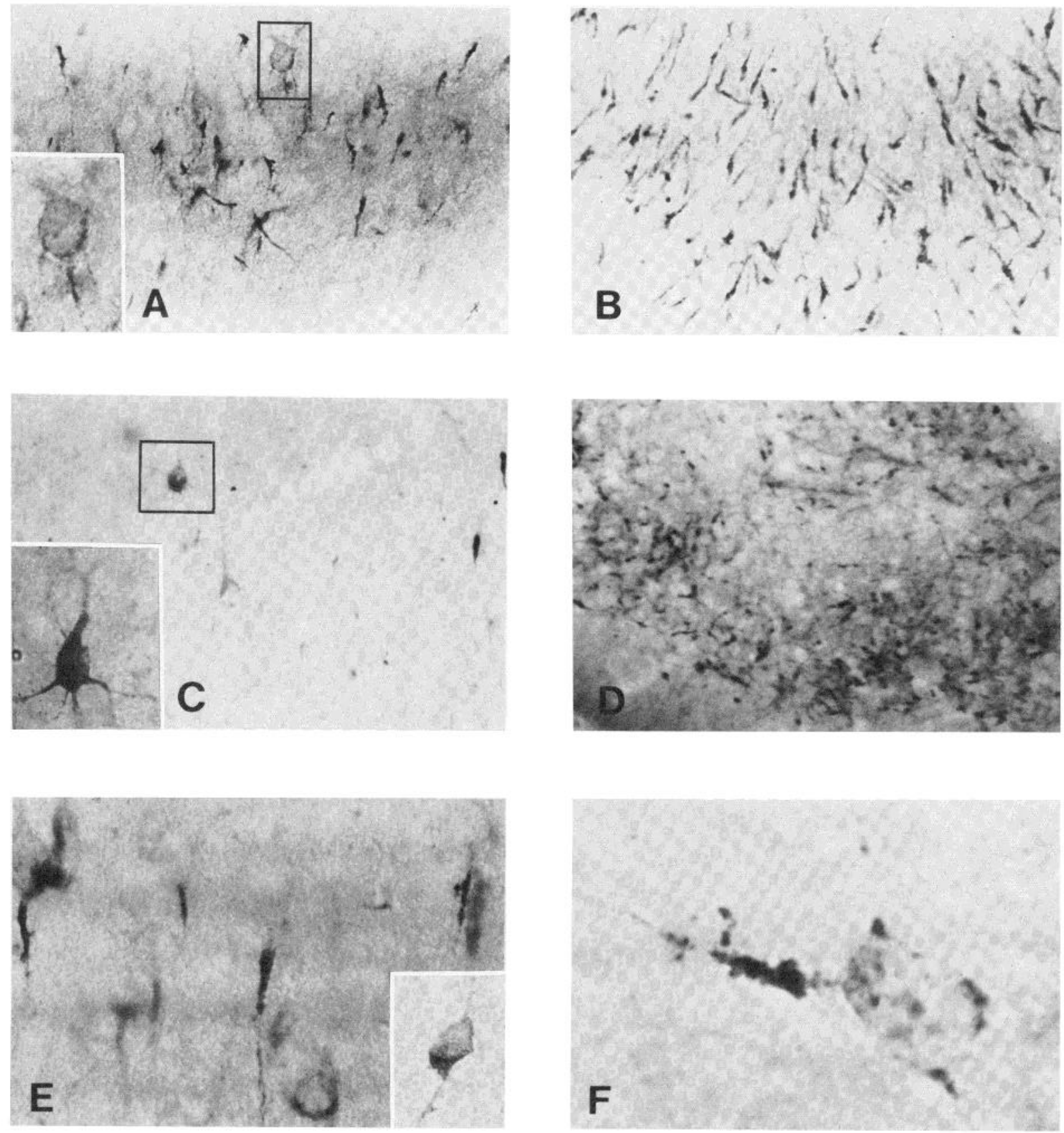

Figure 7. Dynorphin-A immunoreactive cells in the olfactory cortex and neocortex of colchicine-treated Fisher 344 rats. $A$, Layer II of dorsal peduncular cortex. Compare to Figure $3 B(\times 350)$. Inset, Detail of cell boxed in $A(\times 580)$. B, Layer II of ventral tenia tecta. Compare to Figure $3 C(\times 250)$. C , Layers II and III of infralimbic cortex $(\times 275)$ top to left. Inset, Detail of unusually well stained cell boxed in $C(\times 550)$. $D$, Colchicine-induced swollen processes in layers I to III of olfactory tubercle $(\times 300)$. Compare to Figure $3 E(\times 310)$. E, Faintly stained pyramidal cells in layer V of somatosensory cortex $(\times 360)$. Inset, Detail of layer $\mathrm{V}$ cell in temporal cortex $(\times 330)$. F, Faintly stained layer II cell and swollen processes in perirhinal cortex $(\times 830)$.

from our observations that kainic acid-induced intensification of dynorphin and enkephalin immunostaining was not limited to granule cells and mossy fibers of the hippocampal formation (McGinty et al., 1983). While kainic acid is neurotoxic to some cells (presumably by exciting them to death; Olney, 1978), other cells, whose electrical and chemical synthetic activity may be increased, escape degeneration and appear intensely immunostained, sometimes more completely (see dendritic spines in Fig. $4 B$ ) and less pathological looking than after colchicine treatment. Both drugs, however, alter the pattern of cellular immunostaining so that caution must be exercised in correlating such immunoreactive cells with normal cell types. One unexplained observation with regard to kainic acid's effects is why some cells should continue to display increased immunoreactivity weeks (in one case 2 months) after a single kainic acid administration.

The morphological characteristics of the cortical cells containing proenkephalin-ir are compatible with descrip- 
tions of both nonpyramidal (or stellate) cells as well as with pyramidal cells. The nonpyramidal neocortical cells of layers II and III which demonstrate proenkephalin-ir are of at least two major types classified according to their dendritic patterns (Feldman and Peters, 1978): bipolar and multipolar. We cannot claim to have visualized the entire dendritic trees of these neurons, but in favorable cases we were able to observe at least the proximal dendritic branching pattern of a cell which allowed us to make a tentative conclusion as to its type. Proenkephalin-ir is but one example of peptidergic immunostaining of bipolar cells predominantly in layers II and III of neocortex. Bipolar cells contain vasoactive intestinal polypeptide (McDonald et al., 1982b; Morrison, et al., 1984) and cholecystokinin (Peters et al., 1983) as well as somatostatin (Morrison et al., 1983) and corticotropic releasing factor (Swanson et al., 1983). The bipolar cell is the major cell containing proenkephalin-ir in layers II and III of neocortex. In layers V and VI, multipolar cells are the major cell type containing proenkephalin-ir. This bimodal laminar distribution of proenkephalin-immunopositive cells is also apparent in the cortical cell population containing somatostatin-ir (Morrison et al., 1983). Bipolar cells have been shown by Golgi $\mathrm{EM}$ analysis to synapse on the apical dendrites of pyramidal cells (Peters and Kimerer, 1981) among others, which would enable bipolar cell peptides to function in a role of local radial regulation of cortical activity (Morrison et al., 1983).

Other major cell types containing proenkephalin-ir as well as prodynorphin-ir are the pyramidal cells in layer $\mathrm{V}$ of neocortex and layers II and III of olfactory cortex. It is interesting to note that the oval pyramids (Fig. $6 F$ ) stained with BAM22P or enkephalin antiserum in transitional proisocortical/periallocortical regions, such as agranular insular cortex, are intermediate in shape between the round to oval olfactory cortical pyramids (Fig. $4, A$ to $C$ ) and the triangular-shaped pyramids of the neocortex (Fig. $6, G$ and $H$ ). The visualization of immunoreactive fibers crossing from the deep cortical grey into the subcortical white matter supports the finding of opioid peptide-ir in pyramidal cells. However, the possibility that some opioid peptidergic fibers in the white matter may be afferent to the cortex must also be considered.

The regional and laminar distribution of cortical cells containing opioid peptide-ir as presented here is relatively consistent with what might be predicted from opioid binding studies. Early opioid ligand binding studies in brain homogenates demonstrated heavier concentrations of binding sites in limbic-associated cortical regions than in neocortex of rat (Chang et al., 1979), human (Hiller et al., 1973), and monkey (Divac et al., 1981). Autoradiographic analyses of regional opioid binding site distributions also have demonstrated much higher ligand binding in limbic-associated and polysensory (orbitofrontal, temporal, insular) cortex than in primary sensory or motor cortex in rat (Herkenham et al., 1981; Herkenham and Pert, 1982; Lewis et al., 1983) and monkey (Lewis et al., 1981; Wise and Herkenham, 1982 ), in agreement with the regional variations in density of cortical opioid peptidergic-ir. Analyses of the laminar distributions of mu-type opioid binding sites in rats have demonstrated peak $\left[{ }^{3} \mathrm{H}\right]$ naloxone labeling in layers Ia, III or upper V, and VIb (Lewis et al., 1981) where peak opioid peptidergic-ir was found in the present study. (The proenkephalin-immunostained bipolar-like cells and some of the multipolar cells extend their dendrites into layer I.) However, an alternative autoradiographic technique has localized mu-type ligands to layer IV in rats (Goodman et al., 1980; Wamsley et al., 1981), where little or no opioid peptidergic-ir in cells or fibers was found in the present study. Other opioid receptor subtypes have been localized with a predominance in different cortical layers (delta subtype--Goodman et al., 1980; Lewis et al., 1983; kappa subtype-Foote and Maurer, 1982) or different regions (kappa subtypeGoodman and Snyder, 1982; sigma subtype-Quirion et al., 1981; Zukin et al., 1983). Moreover, different selectives of opioid ligand binding are present in cortical (equal binding of mu and delta ligands) and subcortical (a ratio of up to $4 \mathrm{mu}$ to 1 delta binding site) regions (Chang et al., 1979). Nevertheless, precise correlations between the various receptor subtype distributions and the immunocytochemical localization of proenkephalinir and prodynorphin-ir in cortex are not yet apparent.

Because of the strongly emphasized role of opioid peptides in pain perception, it is easiest to provide a hypothetical explanation for the presence of proenkephalin and prodynorphin peptides in limbic-related cortical areas. For example, proenkephalins could mediate the transfer of pain-related information from nociceptive afferents of the submedial thalamic nucleus (Craig et al., 1982) into the periallocortical-proisocortical transitional areas and back down to the lateral periaqueductal grey (Hardy and Leichnetz, 1981). Thus, limbic-associated structures, such as hippocampus (Swanson, 1981) and amygdala (Krettek and Price, 1977b), with connections to these transitional frontal cortical areas, would have access to opioid interneuron routes through which they could influence the perception of pain. While this may be a parsimonious hypothesis, it does not take into account the similar cellular and laminar distributions of the opioid peptides throughout the cerebral cortex. For example, in the olfactory cortcx, layer II pyramidal cells containing opioid peptides may make a significant contribution to the tangential integration of information among paleocortical and archicortical regions through a network of associational and commissural projections (Price, 1973; Haberly and Price, 1978a). In the neocortex, proenkephalin-positive cells may contribute to both tangential and radial processing of polysensory as well as associational cortical information (Buchsbaum et al., 1982; Arnsten et al., 1983; Reisberg et al., 1983). Thus, it is our contention that cortical opioid peptidergic neurons are in a position to influence multiple aspects of cortical information processing, including but not limited to the perception of pain.

\section{References}

Arnsten, A., D. Segal, H. Neville, and S. Hillyard (1983) Naloxone augments electrophysiological measures of selective attention in man. Nature 304: 725-727. 
Bloch, B., A. Baird, N. Ling, R. Benoit, and R. Guillemin (1983) Immunohistochemical evidence that brain enkephalins arise from a precursor similar to adrenal pre-proenkephalin. Brain Res. 263: 251-257.

Bloom, F., and J. McGinty (1981) Cellular distribution and function of endorphins. In Endorphins in Learning and Memory Processes, J. Martinez and J. McGaugh, eds., pp. 199230, Academic Press, Inc., New York.

Buchsbaum, M., V. Reus, G. Davis, H. Holcomb, J. Cappelletti, and E. Silberman (1982) Role of opioid peptides in disorders of attention in psychopathology. Ann. N. Y. Acad. Sci. 398: $352-365$.

Chang, K. -J., B. Cooper, E. Hazum, and P. Cuatrecasas (1979) Multiple opiate receptors: Different regional distribution in the brain and differential binding of opiates and opioid peptides. Mol. Pharmacol. 16: 91-104

Craig, A., S. Wiegand, and J. Price (1982) The thalamo-cortical projection of the nucleus submedius in the cat. J. Comp. Neurol. 206: 28-48.

Divac, I., C. Braestrup, and M. Nielsen (1981) Spiroperidol, naloxone, diazepam and QNB binding in the monkey cerebral cortex. Brain Res. Bull. 7: 469-477.

Feldman, M., and A. Peters (1978) The forms of non-pyramidal neurons in the visual cortex of the rat. J. Comp. Neurol. 179: 761-794.

Finley, J., J. Maderdrut, and P. Petrusz (1981) The immunocytochemical localization of enkephalin in the CNS of the rat. J. Comp. Neurol. 198: 541-565.

Foote, R., and R. Maurer (1982) Autoradiographic localization of opiate k-receptors in the guinea pig brain. Eur. J. Pharmacol. 85: 99-103.

Gall, C., N. Brecha, H. Karten, and K. -J. Chang (1981) Localization of enkephalin-like immunoreactivity to identified axonal and neuronal populations of the rat hippocampus. J. Comp. Neurol. 198: 335-350.

Goldstein, A., and V. Ghazarossian (1980) Immunoreactive dynorphin in pituitary and brain. Proc. Natl. Acad. Sci. U. S. A. 77: 6207-6210.

Goodman, R., and S. Snyder (1982) Autoradiographic localization of kappa opiate receptors to deep layers of the cerebral cortex may explain unique sedative and analgesic effects. Life Sci. 31: 1291-1294.

Goodman, R., S. Snyder, M. Kuhar, and W. Young (1980) Differentiation of delta and mu opiate receptor localization by light microscopic autoradiography. Proc. Natl. Acad. Sci. U. S. A. 77: 6239-6243.

Gros, C., P. Pradelles, C. Rouget, C. Bepoldin, F. Dray, M. Fournie-Laluski, B. Rogues, H. Pollard, C. Llorens-Cortes, and J. Schwartz (1978) Radioimmunoassay of methionine and leucine-enkephalins in regions of rat brain and comparisons with endorphins estimated by a radioreceptor assay. J. Neurochem. 31: 29-39.

Gubler, U., P. Seeburg, B. Hoffman, L. Gage, and S. Udenfriend (1982) Molecular cloning establishes proenkephalin as precursor of enkephalin-containing peptides. Nature 295: 206210.

Haberly, L., and J. Price (1978a) Association and commissural fiber systems of the olfactory cortex of the rat. I. Systems originating in the piriform cortex and adjacent areas. $J$. Comp. Neurol. 178: 711-740.

Haberly, L., and J. Price (1978b) Association and commissural fiber systems of the olfactory cortex of the rat. II. Systems originating in the olfactory peduncle. J. Comp. Neurol. 181: $781-808$.

Hardy, S. G. P., and G. R. Leichnetz (1981) Frontal cortical projections to the periaqueductal gray in the rat: A retrograde and orthograde horseradish peroxidase study. Neurosci. Lett. 23: $13-17$.
Heimer, L., and R. Kalil (1978) Rapid transneuronal degeneration and death of cortical neurons following removal of the olfactory bulb in adult rats. J. Comp. Neurol. 178: 559-610.

Herkenham, M. (1981) Autoradiographic localization of opiate receptors in the cortex, thalamus and amygdala of the rat. Anat. Rec. 199: 111A-112A.

Herkenham, M., and C. Pert (1982) Light microscopic localization of brain opiate receptors: A general autoradiographic method which preserves tissue quality. J. Neurosci. 2: 11291149.

Herkenham, M., S. Edley, and C. Pert (1981) Opiate receptor distribution in mammalian cortex: A comparative autoradiographic study. Soc. Neurosci. Abstr. 7: 436.

Hiller, J., J. Pearson, and E. Simon (1973) Distribution of stereospecific binding of the potent narcotic analgesic etorphine in the human brain: Predominance in the limbic system. Res. Commun. Chem. Pathol. Pharmacol. 6: 1052-1062.

Hindelang-Gertner, C. (1976) Colchicine effects on neurosecretory neurons and other hypothalamic and hypophysial cells, with special reference to changes in the cytoplasmic membranes. Cell Tissue Res. 170: 17-41.

Hollt, V., I. Haarmann, K. Bovermann, M. Jerlicz, and A. Herz (1980) Dynorphin-related immunoreactive peptides in rat brain and pituitary. Neurosci. Lett. 18: 149-153.

Hollt, V., I. Haarmann, C. Grimm, A. Herz, F. Tulunay, and H. Loh (1982) Pro-enkephalin intermediates in bovine brain and adrenal medulla: Characterization of immunoreactive peptides related to BAM $22 \mathrm{P}$ and peptide E. Life Sci. 31: 1883-1886.

Hughes, J., H. Kosterlitz, and T. Smith (1977) The distribution of methionine-enkephalin and leucine-enkephalin in the brain and peripheral tissues. Br. J. Pharmacol. 61: 639-647.

Jaffe, J., and W. Martin (1980) Opioid analgesics and antagonists. In The Pharmacological Basis of Therapeutics, Ed. 6, L. S. Goodman and A. Gilman, eds., pp. 494-534, Macmillan, New York.

Kakidani, H., Y. Furutani, H. Takahashi, M. Noda, Y. Morimoto, T. Hirose, M. Asai, S. Inayama, S. Nakanishi, and S. Numa (1982) Cloning and sequence analysis of cDNA for porcine B-neo-endorphin/dynorphin, precursor. Nature 298: $245-248$.

Khachaturian, H., S. Watson, M. Lewis, D. Coy, A. Goldstein, and H. Akil (1982a) Dynorphin immunocytochemistry in the rat central nervous system. Peptides 3: 941-954.

Khachaturian, H., M. Lewis, and S. Watson (1982b) Immunocytochemical studies with antisera against leu-enkephalin and an enkephalin-precursor fragment (BAM 22P) in the rat brain. Life Sci. 31: 1879-1882.

Khachaturian, H., M. Lewis, V. Hollt, and S. Watson (1983) Telencephalic enkephalinergic systems in the rat brain. J. Neurosci. 3: 844-855.

Krettek, J., and J. Price (1977a) The cortical projections of the mediodorsal nucleus and adjacent thalamic nucleus in the rat. J. Comp. Neurol. 171: 157-192.

Krettek, J., and J. Price (1977b) Projections from the amygdaloid complex to the cerebral cortex and thalamus in the rat and cat. J. Comp. Neurol. 172: 687-722.

Lewis, M., M. Mishkin, E. Bragin, R. Brown, C. Pert, and A. Pert (1981) Opiate receptor gradients in monkey cerebral cortex: Correspondence with sensory processing hierarchies. Science 211: 1166-1169.

Lewis, M., A. Pert, C. Pert, and M. Herkenham (1983) Opiate receptor localization in rat cerebral cortex. J. Comp. Neurol. 216: 339-358.

Lcwis, R., S. Stein, L. Gerber, M. Rubinstein, and S. Udenfriend (1978) High molecular weight opioid-containing proteins in striatum. Proc. Natl. Acad. Sci. U. S. A. 75: 40214023 . 
Liston, D., J. J. Vanderhaeghen, and J. Rossier (1983) Presence in brain of synenkephalin, a proenkephalin-immunoreactive protein which does not contain enkephalin. Nature 302: 6265.

McDonald, J., J. Parnavelas, A. Karamanlidis, N. Brecha, and J. Koenig. (1982a) The morphology and distribution of peptide-containing neurons in the adult and developing visual cortex of the rat. I. Somatostatin. J. Neurocytol. 11: 809-824.

McDonald, J., J. Parnavelas, A. Karamanlidis, and N. Brecha (1982b) The morphology and distribution of peptide-containing neurons in the adult and developing visual cortex of the rat. II. Vasoactive intestinal polypeptide. J. Neurocytol. 11: 825-837.

McGinty, J., L. Terenius, and F. Bloom (1982a) Immunocytochemical localization of dynorphin immunoreactivity in rat CNS. Soc. Neurosci. Abstr. 8: 98.

McGinty, J., D. van der Kooy, L. Koda, and F. Bloom (1982b) Enkephalin immunoreactive cells in frontal, olfactory, and limbic cortex. Anat. Rec. 202: 125A.

McGinty, J. F., S. J. Henriksen, A. Goldstein, L. Terenius, and F. E. Bloom (1983) Dynorphin is contained within hippocampal mossy fibers: Immunochemical alterations following kainic acid administration and colchicine-induced neurotoxicity. Proc. Natl. Acad. Sci. U. S. A. 80: 589-593.

Miller, R. (1981) Peptides as neurotransmitters: Focus on the enkephalins and endorphins. Pharmacol. Ther. (B) 12: 73108.

Miller, R., J. -K. Chang, and P. Cuatrecasas (1978) Radioimmunoassay and characterization of enkephalins in rat tissues. J. Biol. Chem. 253: 531-538.

Minamino, N., K. Kitamura, Y. Hayashi, K. Kangawa, and H. Matsuo (1981) Regional distribution of $\alpha$-neo-endorphin in rat brain and pituitary. Biochem. Biophys. Res. Commun. 102: 226-234.

Morrison, J., R. Benoit, P. Magistretti, and F. Bloom (1983) Immunohistochemical distribution of pro-somatostatin related peptides in cerebral cortex. Brain Res. 262: 344-351.

Morrison, J., P. Magistretti, R. Benoit, and F. Bloom (1984) The distribution and morphological characteristics of the intracortical VIP-positive cell: An immunohistochemical analysis. Brain Res. 292: 269-282.

Nakanishi, S., A. Inoue, J. Kita, M. Nakamura, A. Chang, S. Cohen, and S. Numa (1979) Nucleotide sequence of cloned cDNA for bovine corticotropin/ $\beta$-lipotropin precursor. $\mathrm{Na}$ ture 278: 423-428.

Nicoll, R., G. Siggins, N. Ling, and F. Bloom (1977) Neuronal actions of endorphins and enkephalins among brain regions: A comparative microiontophoretic study. Proc. Natl. Acad. Sci. U. S. A. 74: 2584-2588.

Noda, M., Y. Furutani, H. Takahashi, M. Toyosato, T. Hirose, S. Inayama, S. Nakanishi, and S. Numa (1982) Cloning and sequence analysis of cDNA for bovine adrenal pre-proenkephalin. Nature 295: 202-206.

Olney, J. (1978) Neurotoxicity of excitatory amino acids. In Kainic Acid as a Tool in Neurobiology, E. McGeer, ed., pp. 95-121, Raven Press, New York.

Paxinos, G., and C. Watson (1982) The Rat Brain in Stereotaxic Coordinates, Academic Press, Inc., New York.

Peters, A., and K. Kimerer (1981) Bipolar neurons in rat visual cortex: A combined Golgi-electron microscope study. J. Neurocytol. 10: 921-946.

Peters, A., M. Miller, and K. Kimerer (1983) Cholecystokininlike immunoreactive neurons in rat cerebral cortex. Neuroscience 8: 431-448.

Price, J. (1973) An autoradiographic study of complementary laminar patterns of termination of afferent fibers to the olfactory cortex. J. Comp. Neurol. 150: 87-108.

Quirion, R., R. Hammer, M. Herkenham, and C. Pert (1981) Phencyclidine (angel dust) $/ \delta$-"opiate" receptor: Visualization by tritium-sensitive film. Proc. Natl. Acad. Sci. U. S. A. 78: $5881-5885$.

Ramón y Cajal, S. (1911) Histologie du Système Nerveux de l'Homme et des Vertébrés, Vol. 2, Maloine, Paris.

Reep, R., and S. Winans (1982) Afferent connections of dorsal and ventral agranular insular cortex in the hamster Mesocricetus auratus. Neuroscience 7: 1265-1288.

Reisberg, B., H. Ferris, R. Anand, P. Mir, V. Geibel, M. De Leon, and E. Roberts (1983) Effects of naloxone in senile dementia: A double blind trial. N. Engl. J. Med. 308: 721722.

Sar, M., W. E. Stumpf, R. J. Miller, K. Chang, and P. Cuatrecasas (1978) Immunohistochemical localization of enkephalin in rat brain and spinal cord. J. Comp. Neurol. 182: 17-38.

Satoh, M., W. Zieglgansberger, W. Fries, and A. Herz (1974) Opiate agonist-antagonist interaction at cortical neurons of naive and tolerant/dependent rats. Brain Res. 82: 378-382.

Satoh, M., W. Zieglgansberger, and A. Herz (1976) Actions of opiates upon single unit activity in the cortex of naive and tolerant rats. Brain Res. 115: 99-110.

Simantov, R., S. Childers, and S. Snyder (1977) Opioid peptides: Differentiation by radioimmunoassay and radioreceptor assay. Brain Res. 135: 358-367.

Swanson, L. (1981) A direct projection from Ammon's horn to prefrontal cortex in the rat. Brain Res. 217: 150-154.

Swanson, L., P. Sawchenko, J. Rivier, and W. Vale (1983) The organization of ovine corticotropin releasing factor (CRF)immunoreactive cells and fibers in the rat brain: An immunohistochemical study. Neuroendocrinology 36: 165-186.

Vincent, S., T. Hökfelt, I. Christensson, and L. Terenius (1982) Dynorphin-immunoreactive neurons in the central nervous system of the rat. Neurosci. Lett. 33: 185-190.

Wamsley, J. K., W. S. Young, and M. J. Kuhar (1980) Immunohistochemical localization of enkephalin in rat forebrain. Brain Res. 190: 153-174.

Wamsley, J. K., W. S. Palacios, W. S. Young, and M. J. Kuhar (1981) Autoradiographic determination of neurotransmitter receptor distributions in the cerebral and cerebellar cortices. J. Histochem. Cytochem. 29: 125- 135.

Weber, E., C. Evans, and J. Barchas (1982a) Opioid peptide dynorphin: Predominance of the aminoterminal octapeptide fragment in rat brain regions. Nature 299: 77-79.

Weber, E., K. Roth, and J. Barchas (1982b) Immunohistochemical distribution of $\alpha$-neo-endorphin/dynorphin neuronal systems in rat brain: Evidence for colocalization. Proc. Natl. Acad. Sci. U. S. A. 79: 3062-3066.

Wise, S., and M. Herkenham (1982) Opiate receptor distribution in the cerebral cortex of the rhesus monkey. Science 218: 387-389.

Yang, H.-Y., J. S. Hong, and E. Costa (1977) Regional distribution of Leu and Met enkephalin in rat brain. Neuropharmacology 16: 303-307.

Zilles, K., B. Zilles, and A. Schleicher (1980) A quantitative approach to cytoarchitectonics. VI. The areal pattern of the cortex of the albino rat. Anat. Embryol. 159: 335-360.

Zukin, R. S. (1983) Opiate receptors: Current issues and methodologies. In Methods in Neurobiology, R. Marangos, ed., Plenum Press, New York, in press.

Zukin, S. R., M. Fitz-Syage, R. Nichtenhauser, and R. S. Zukin (1983) Specific binding of $\left[{ }^{3} \mathrm{H}\right]$ phencyclidine in rat central nervous tissue: Further characterization and technical considerations. Brain Res. 258: 277-284. 